\title{
GCU
}

Glasgow Caledonian

University

University for the Common Good

\section{Measuring self-regulated learning in the workplace}

Fontana, Rosa Pia; Milligan, Colin; Littlejohn, Allison; Margaryan, Anoush

Published in:

International Journal of Training and Development

DOI:

$10.1111 / \mathrm{ijtd} .12046$

Publication date:

2015

Document Version

Early version, also known as pre-print

Link to publication in ResearchOnline

Citation for published version (Harvard):

Fontana, RP, Milligan, C, Littlejohn, A \& Margaryan, A 2015, 'Measuring self-regulated learning in the workplace', International Journal of Training and Development, vol. 19, no. 1, pp. 32-52.

https://doi.org/10.1111/ijtd.12046

\section{General rights}

Copyright and moral rights for the publications made accessible in the public portal are retained by the authors and/or other copyright owners and it is a condition of accessing publications that users recognise and abide by the legal requirements associated with these rights.

Take down policy

If you believe that this document breaches copyright please view our takedown policy at https://edshare.gcu.ac.uk/id/eprint/5179 for details of how to contact us. 
This is a yellow-archive copy of the pre-print. Please find the final article at http://onlinelibrary.wiley.com/doi/10.1111/ijtd.12046/abstract and cite as: Fontana, R.P., Milligan, C., Littlejohn, A., and Margaryan, A. (2015) Measuring self-regulated learning in the workplace. International Journal of Training and Development. 19 (1) 32-52.

\title{
Measuring self-regulated learning in the workplace Rosa Pia Fontana, colin Milligan, Allison Littlejohn, Anoush Margaryan
}

\begin{abstract}
In knowledge intensive industries, the workplace has become a key locus of learning. To perform effectively, knowledge workers must be able to take responsibility for their developmental needs, and in particular, to self-regulate their learning. This paper describes the construction and validation of an instrument (the Self-Regulated Learning at Work Questionnaire: SRLWQ) designed to provide a measure of self-regulated learning behaviour in the workplace. The instrument has been validated with a cohort of knowledge workers from the finance industry $(n=170)$. Results indicate that the five scales of the instrument are reliable and valid, testing a broad range of sub-processes of selfregulated learning. The instrument can be used to identify knowledge workers who demonstrate different levels of self-regulated learning in workplace contexts for further exploration through qualitative studies and could also provide the basis of professional development tools designed to explore opportunities for self-regulation of learning in the workplace.
\end{abstract}

Keywords: workplace learning, self-regulated learning,

\section{Introduction}

In today's knowledge intensive workplaces, there is a need for learning to occur continually as workers solve complex and novel work problems (Hager, 2004). In knowledge intensive workplaces, formal training approaches have become less effective and appropriate as each worker's learning needs are bespoke and change continually (Littlejohn \& Margaryan, 2013). In these workplaces, learning is primarily achieved through intentional informal learning that is deeply intertwined with everyday work tasks. (Tynjälä, 2008; Eraut, 2007). Responsibility for learning shifts from the training department to the learner, who must manage their own learning for work. Individual workers plan and evolve their learning by setting learning goals, monitoring progress, and adapting strategies to suit precise learning requirements (Schulz \& Stamov Roßnagel, 2010). These processes mirror the sub-processes of self-regulated learning (Zimmerman, 2000).

As part of a larger study examining the workplace learning strategies of knowledge workers, this study aimed to develop a valid and reliable measure of self-regulation of learning that could be efficiently deployed in knowledge work contexts. The purpose of this paper is to describe the design of the instrument and report its internal reliability and predictive validity. This paper begins with a review of models of self-regulated learning and their application in the workplace, as well as how SRL has been measured in formal education and the potential value of similar measures in workplace contexts. The next section describes how the instrument was constructed from a number of existing measures, adapting these, as necessary, to the workplace context. Then, an initial statistical validation of the instrument in a population of knowledge workers drawn from the finance industry is presented. Internal reliability is explored through calculation of Cronbach alpha values and principal component analysis. Predictive validity is explored through correlation analysis with workplace learning activity. The paper concludes with a discussion of the initial results provided in this study, and reflects on the limitations of the instrument and its potential value in opening up new approaches to examining knowledge worker learning in the workplace.

\subsection{Self-regulated Learning}

Self-regulation is the 'self-generated thoughts, feelings and actions that are planned and cyclically adapted to the attainment of personal goals' (Zimmerman, 2000). Self-regulated learning (SRL) has been studied extensively in formal educational contexts leading to the development of a number of closely related models of self-regulated learning (see Puustinen \& Pulkkinen (2001) for a comparative review) including those outlined by Zimmerman (2000) and Pintrich (2000). The models 
This is a yellow-archive copy of the pre-print. Please find the final article at http://onlinelibrary.wiley.com/doi/10.1111/ijtd.12046/abstract and cite as: Fontana, R.P., Milligan, C., Littlejohn, A., and Margaryan, A. (2015) Measuring self-regulated learning in the workplace. International Journal of Training and Development. 19 (1) 32-52.

are united by their adoption of a phased and cyclical view of the regulation of learning where, for instance, self-reflection of previous learning efforts affects subsequent goal-setting (Zimmerman \& Kitsantas, 1999). Zimmerman's model of self-regulated learning (Zimmerman, 1989, 2000) takes as its starting point Bandura's social cognitive theory (1986), elaborating a model that describes the self-regulation of learning by recognising three principal phases: forethought, performance and selfreflection (Zimmerman, 2000). Within the three phases, Zimmerman's work has identified a number of sub-processes describing the different SRL behaviours an individual may enact as they selfregulate their learning (see Table 1 for the list reported in Zimmerman, 2011). Pintrich (2000) describes a four phase framework, emphasising monitoring as a discrete phase alongside, planning, control and reflection phases that correspond closely to Zimmerman's phases. Within Pintrich's framework, a similar range of behaviours are described, adopting a slightly different vocabulary. For instance, Pintrich's framework includes learning strategies such as elaboration and critical thinking.

\begin{tabular}{l|lll}
\hline Phases & Forethought & Performance & Self-reflection \\
\hline Sub-processes & Goal setting & Task strategies & Self-evaluation \\
& Strategic planning & Colition strategies & Self-satisfaction/affect \\
& Self-efficacy & Self-instruction & Adaptive/defensive \\
& Outcome expectations & Imagery & \\
& Task interest/value & Time management & \\
& Goal orientation & Environmental structuring & \\
& & Help-seeking & \\
& & Interest enhancement & \\
& & Self-consequences & \\
& & Metacognitive monitoring & \\
& & Self-recording &
\end{tabular}

Table 1. SRL phases and sub-processes as outlined by Zimmerman (2011)

Using these models as their base, a number of quantitative instruments designed to measure SRL and its sub-processes have been developed (for example Pintrich, Smith, Garcia \& McKeachie, 1991). The use of these instruments in formal educational contexts has established a link between higher SRL scores and positive academic outcomes. These instruments have subsequently been used to develop interventions to enhance and promote self-regulatory behaviour (Hofer, Yu \& Pintrich, 1998). The development of an equivalent measure for workplace contexts would allow analysis of the different workplace learning behaviours of high and low self-regulating learners in the workplace, as well as guiding development of interventions which would foster and support the development of these SRL behaviours in the workplace.

A recent meta-analysis of self-regulated learning in formal training contexts illustrated the extent to which SRL theories have shaped our understanding of how individuals adapt their learning behaviour (Sitzmann \& Ely, 2011), emphasising particularly the goal-oriented nature of work-related learning. Sitzmann and Ely (2011) argue that self-regulation is likely to have an even greater impact on learning in informal situations, for instance where workers have to identify or create their own learning opportunities (Enos, Kehrhahn \& Bell, 2003) or when it is critical that workers are able to monitor their own learning effectively. van Eekelen, Boshuizen and Vermunt (2005) conducted a qualitative study exploring teachers' self-regulated learning occurring during practice. The study used qualitative instruments (interviews and diaries) to gather data about instances of learning termed 'learning episodes'. van Eekelen and colleagues found evidence of teachers changing their practice, which was assumed to be a sign of learning but uncovered little evidence of self-regulation during learning episodes which were largely externally regulated. Another qualitative study, conducted by Margaryan, Littlejohn, and Milligan (2013) explored how knowledge workers in a multinational energy company planned and attained their learning. The authors found evidence of workers self-regulating their learning. However, their SRL practices were not delineated into discrete phases, as described in conventional SRL models. Taken together, the studies by van Eekelen et al 
This is a yellow-archive copy of the pre-print. Please find the final article at http://onlinelibrary.wiley.com/doi/10.1111/ijtd.12046/abstract and cite as: Fontana, R.P., Milligan, C., Littlejohn, A., and Margaryan, A. (2015) Measuring self-regulated learning in the workplace. International Journal of Training and Development. 19 (1) 32-52.

and Margaryan et al indicate that informal learning in the workplace, that is continual, dynamic and deeply intertwined with work goals may not occur precisely as described by SRL theories originating from formal education, but does involve the same range of sub-processes. By looking at these subprocesses in detail, we can improve our understanding of which sub-processes are most important for informal workplace learning.

Schulz \& Stamov Roßnagel (2010) adapted a German translation of the Motivated Strategies for Learning Questionnaire devised by Pintrich et al (1991) to fit a workplace context by altering the wording and eliminating items not relevant for workplace learning. The authors then used the adapted items to explore informal workplace learning in a mail order company. This study concluded that an individual's ability to self-regulate his/her learning (described by the authors as 'learning competence' drawing on previous work by van den Boom, Paas, van Merrienboer, \& van Gog, 2004) was a predictor of (self-identified) success in informal learning. The study identified specific SRL sub processes that are important attributes of successful learners, including the ability to set learning goals, to plan, monitor and evaluate learning, and possessing a positive learning orientation. Other studies have explored specific aspects of self-regulation using quantitative measures that target specific sub-processes or groups of sub-processes. Warr and Downing (2000) explored learning strategies of adult technical trainees, linking particular strategies such as rehearsal and written helpseeking to knowledge change as a measure of learning success. Rigotti, Schyns and Mohr (2008) developed a measure of self-efficacy matched to workplace roles as a tool to explore self-efficacy across organisational contexts. To date however there is no single instrument that incorporates the broad range of SRL behaviours identified by Zimmerman and Pintrich.

Not all studies exploring informal intentional learning in the workplace have focused on selfregulation of learning. In a study of information and communication technology (ICT) workers, Gijbels, Raemdonck, Vervecken and van Herck (2012) used the related concept of Self-Directed Learning (SDL) to explore how an individual's Self-Directed Learning Orientation (SDLO) influences their participation in work-related learning. SRL and SDL are closely linked concepts (Pilling-Cormick \& Garrison, 2011) focused on individual control of the processes of setting goals and priorities for learning. The two concepts have different origins with SRL emphasising the internal (motivational and cognitive) processes of learning while SDL focuses on external control. Gijbels et al (2012) found that SDLO is a significant and strong predictor of work-related behaviour. One criticism of the Gijbels study is that SDLO is a single construct and therefore while the Gijbels study demonstrated that learners who score highly on a SDLO scale take up more learning opportunities over a fixed time period, it is difficult to dissect this relationship further. The use of an instrument based on SRL would allow the identification of specific sub-processes highlighting particular behaviours which predict work-related learning success.

In formal education, self-report instruments such as the Motivated Strategies for Learning Questionnaire (MSLQ: Pintrich et al, 1991), or the Metacognitive Awareness inventory (MAI: Schraw \& Dennison, 1994), have proved useful in providing reliable measures of SRL behaviour in a variety of contexts (Barnard-Brak, Lan \& Paton, 2011). Self-report instruments can be deployed efficiently to large cohorts and facilitate statistical analyses which can highlight associations between SRL 'scores' and other behaviours and factors. Self-report measures are recognised as imperfect, with researchers such as Winne and Jamieson-Noel (2002) demonstrating that learners over-estimate their ability when compared to more objective measures such as observation or trace based methods. However, self-report is a useful method for collecting data on the implicit variables inherent in on-the-job learning that are difficult to measure (Berings et al., 2006). Although individuals may not be capable of accurately reporting on inner processes, they are able to validly answer questions about a variety of constructs including their moods, attributes, plans, attitudes, and beliefs (see Ericsson \& Simon, 1980; Haeffel \& Howard, 2010). Other studies have indicated that 
This is a yellow-archive copy of the pre-print. Please find the final article at http://onlinelibrary.wiley.com/doi/10.1111/ijtd.12046/abstract and cite as: Fontana, R.P., Milligan, C., Littlejohn, A., and Margaryan, A. (2015) Measuring self-regulated learning in the workplace. International Journal of Training and Development. 19 (1) 32-52.

self-report measures are sufficiently reliable in measuring behaviours in real world contexts (Chan, 2009). The goal of this study was to develop a quantitative instrument that would able to differentiate between individuals exhibiting high and low levels of SRL behaviour. The SRL score generated by the instrument is intended as a relative, rather than absolute measure, and therefore the use of a self-report instrument is valid. Similar studies such as those by Schulz and Stamov Roßnagel (2010), and Warr and Downing (2000) have utilised self-report instruments.

\section{Instrument Construction}

The availability of a large number of pre-existing validated instruments such as the MSLQ (Pintrich et al, 1991) to assess SRL activity provides a useful starting point for the development of a new SRL instrument. Rather than create new items, the strategy followed for the development of the SelfRegulated Learning in the Workplace Questionnaire was to review a range of existing instruments, selecting those items which addressed aspects of self-regulation judged to be relevant within the workplace context and adapting the wording of items to reflect the workplace setting. This approach reflects that of Schulz and Stamov Roßnagel (2010) who developed a similar instrument by adapting a German language version of the MSLQ.

While this instrument is designed primarily to provide a measure of self-regulated learning behaviour (as measured by three separate scales corresponding to the three phases of self-regulated learning identified by Zimmerman (2000)), two further scales were also included in the instrument. First, a scale was designed that could provide a measure of (primarily informal) learning an individual has undertaken recently (the Workplace Learning Activity scale). The workplace learning activity scale will be used in correlation analysis to explore the predictive validity of the SRL scales. Second, a scale intended to provide a measure of the opportunities for learning available to each respondent was included (the Workplace Learning Context scale). Learning may be affected by role characteristics such as whether there are opportunities to interact with different people, to be creative, or to solve problems and the WLC scale allows these non-individual factors to be accounted for. The design and development of all five scales is described below.

\subsection{Workplace Learning Activity scale: WLA}

The first scale in the instrument is designed to provide a measure of the recent workplace learning activities undertaken by respondents. To measure this variable a custom scale was designed by searching the literature regarding informal workplace learning. A number of studies had attempted to develop similar measures including: Gijbels et al. (2012), who studied how an individual's ability to self-direct their learning affected the learning activities they undertook; Schulz and Stamov Roßnagel (2010), who examined recent informal learning in a study exploring the effect of age differences on learning competence; and Crouse, Doyle and Young (2011), who defined a set of learning activity types abstracted from a literature review of informal learning activities in the workplace. By collecting and reviewing the items developed by these authors, a scale containing a broad set of learning activities undertaken by knowledge workers was designed. The scale consists of 11 items (example item: How frequently have you participated in the following learning activities in the last year? Acquiring new information (e.g. by searching the internet or company knowledge base) from 1 $=$ rarely or never, to $5=$ very often or continually). This scale was placed at the beginning of the instrument to focus respondents' attention on this range of informal learning activities prior to responding to the other items of the instrument.

\subsection{Self-regulated learning scales (SRL-F, SRL-P, SRL-SR)}

The next three scales are designed to provide a measure of an individual's ability to self-regulate their learning. Although related, the three scales are discrete, and relate to the three phases of selfregulated learning described by Zimmerman (2000): forethought, performance, and self-reflection. Using Zimmerman's list of sub-processes as a starting point (Table 1), the authors sought to develop 
This is a yellow-archive copy of the pre-print. Please find the final article at http://onlinelibrary.wiley.com/doi/10.1111/ijtd.12046/abstract and cite as: Fontana, R.P., Milligan, C., Littlejohn, A., and Margaryan, A. (2015) Measuring self-regulated learning in the workplace. International Journal of Training and Development. 19 (1) 32-52.

an instrument (the Self-Regulated Learning at Work Questionnaire: SRLWQ) covering a broad range of learning behaviours relevant to intentional informal learning in the workplace. The list of subprocesses identified by Zimmerman was reviewed. Sub-processes linked closely to formal education (for example: self-instruction, attention focusing, environmental structuring and imagery) were excluded. Two additional sub-processes (strategies: elaboration and critical thinking) identified in Pintrich's work and considered particularly relevant to workplace contexts were included. This review resulted in the phase/sub-process structure as presented in Table 2.

\begin{tabular}{l|lll}
\hline Phase & Forethought & Performance & Self-reflection \\
\hline Sub-processes & Goal setting & Task strategies & Self-evaluation \\
& Strategic planning & Elaboration & Self-satisfaction/affect \\
& Self-efficacy & Critical Thinking & \\
& Task interest/value & Help seeking & \\
& & Interest enhancement & \\
\hline
\end{tabular}

\section{Table 2 Phases and sub-processes included in SRLWQ}

Next, the authors reviewed a number of previously validated instruments designed to measure SRL or its sub-processes. Items from five instruments (see below) were selected in order that each subprocess should be covered by a range of items. In summary, the three SRL scales were structured as follows. The scale measuring the forethought phase consisted of 17 items representing four subprocesses. The scale measuring the performance phase included 19 items representing five subprocesses. Finally, the scale designed to measure self-reflection consisted of six items representing two sub-processes.

The five instruments used as sources for items were:

- Motivated Strategies for Learning Questionnaire (MSLQ: Pintrich et al., 1991). This instrument is composed of 81 items designed to assess students' motivational orientation in their use of different learning strategies and covers a comprehensive range of SRL subprocesses. The original instrument utilises a 7 point Likert scale (from $1=$ not at all true to 7 = very true for $\mathrm{me}$ ) and consists of three sections: motivation (31 items), learning strategies (31) and resource management (19 items). This instrument is closely aligned to Pintrich's framework of phases and areas of regulation (Pintrich, 2000) and was originally applied in formal higher education. 16 items were used from this instrument (example item: (MSLQ64) 'When reading for this class, I try to relate the material to what I already know' reworded as SRLWQ-29: 'When I'm learning, I try to relate new knowledge I find to what I already know').

- Learning Strategies Questionnaire (LS: Warr \& Downing, 2000). This instrument originated from the domain of organisational psychology and consists of 21 items measuring six aspects (reproduction, extrinsic and intrinsic work reflection, interpersonal help seeking, help seeking from written material, and practical application) of workplace learning behaviour. Five items of the scale were used in the instrument, slightly reworded to match the style of other items (example item: (LS-10) 'I generally try to understand how new information fits in to how I do my work' was reworded as SRLWQ-47: 'I try to understand how new information I've learned impacts my work').

- Occupational self-efficacy scale (OS: Rigotti et al., 2008). Self-efficacy is defined as the confidence an individual has in her or his ability to cope with difficult tasks or problems or: the belief in one's own ability to successfully fulfil a task (Bandura, 1977). In organisational research, the concept of self-efficacy is viewed as a domain-specific component, referring to the competence that an individual perceives he or she has concerning their ability to successfully fulfil the tasks involved in his or her job (Rigotti et al., 2008). This six-item scale came originally from an organisational psychology context, and was used in its entirety 
This is a yellow-archive copy of the pre-print. Please find the final article at http://onlinelibrary.wiley.com/doi/10.1111/ijtd.12046/abstract and cite as: Fontana, R.P., Milligan, C., Littlejohn, A., and Margaryan, A. (2015) Measuring self-regulated learning in the workplace. International Journal of Training and Development. 19 (1) 32-52.

without rewording (for example: '(OS-1/SRLWQ-48) I can remain calm when facing difficulties in my job because I can rely on my abilities').

- Metacognitive Awareness inventory (MAI: Schraw \& Dennison, 1994). This 52 item instrument (evaluated by true/false answers and an accompanying scoring guide) is underpinned by a two factor model of metacognition which includes reflective aspects of learning and regulation of cognition. This scale has been validated in higher education. 11 items were selected, reworded for the workplace context, and adapted to fit a 5-point Likert scale. (example item: (MAI-22) 'I ask myself questions about the material before I begin' reworded as SRLWQ-16: 'I ask myself questions about each learning task before I begin').

- Online Self-Regulated Learning Questionnaire (OSLQ: Barnard-Brak, Lan \& Paton, 2010). This instrument, based directly on Zimmerman's model, consists of 24 statements designed to measure the respondent's ability to self-regulate their learning in environments that are wholly or partially online. Four items from this scale were used (example item: (OSLQ-1) ' set standard for my assignments in online courses' reworded as SRLWQ-12: 'I set personal standards for performance in my job').

\subsection{Workplace Learning Context Scale: WLC}

The ability and capacity to learn is an individual characteristic but learning may also be context dependent, and therefore it was important that the instrument also included a measure of the workplace context in which each respondent is working. Learning may be affected by role characteristics such as whether there are opportunities to interact with different people, to be creative, or to solve problems. An existing scale, developed by Schalk and van Woerkom (2009) as part of a study investigating the relationship between age, workplace context, and employability was included in the instrument. The scale is comprised of six items designed to provide a measure of the learning opportunities available to the individual in their particular workplace/role context. As the scale was originally designed for a workplace context, no rewording was necessary and the scale was used unaltered (example item: (WLC-1/SRLWQ-54) 'My job requires me to be creative').

Items to collect demographic information (age, role, number of years in current organisation) were also included to provide a simple profile of the sample measured. A full list of items from the SRLWQ instrument is included as an appendix to this paper and online at http://db.tt/SeUkol7S. The instrument was piloted internally within the research group, and also with a small sample from the target audience to check for problems with format, length, wording, clarity, and coherence. This phase resulted in only minor changes to the wording of some items and accompanying guidance.

\subsection{Sample and analysis}

Participants were knowledge workers in the finance industry. The sample cohort for this study was provided by the Chartered Institute for Securities and Investment (CISI), and other professional development bodies serving the finance industry. The instrument was made available online and a link distributed on member mailing lists. These mailing lists have approximately 15,000 subscribers. 240 responses were collected within a three-week time period in early 2013 . By eliminating those participants who did not fully complete the survey instrument, the sample was reduced to 170 . While the professional bodies are based in the United Kingdom, their membership is international. The sample comprised 99 male and 71 female respondents. The average age of respondents was 38.12 years old $(S D=10.97)$. Respondents reported a range of work roles: 38 senior managers, 41 supervisors and 91 frontline staff. The average time worked in the current organisation was 9.3 years $(S D=10.73)$. SRL scores for each participant were derived by adding the scores for the three SRL scales. The minimum and maximum scores observed were 92 and 207 respectively (the possible range was from 42-210). The average SRL score obtained was $155.19(S D=21.8)$.

The dataset was analysed with the SPSS software package. Statistical analysis was conducted to 
This is a yellow-archive copy of the pre-print. Please find the final article at http://onlinelibrary.wiley.com/doi/10.1111/ijtd.12046/abstract and cite as: Fontana, R.P., Milligan, C., Littlejohn, A., and Margaryan, A. (2015) Measuring self-regulated learning in the workplace. International Journal of Training and Development. 19 (1) 32-52.

determine the utility of the instrument in terms of internal reliability (Cronbach Alpha) and predictive validity (Pearson Correlation). In order to understand the underlying constructs in the scales, a principal component analysis (Darlington, Weinberg \& Walberg, 1973) was conducted for each of the five scales using Varimax (orthogonal) rotation when more than one factor could be extracted. The results of this analysis are described below.

\section{Results and discussion}

\subsection{Internal reliability of the scales}

Internal reliability of the instruments was measured by calculating Cronbach Alpha values for the five scales. All five scales showed Cronbach Alphas greater than 0.8 , indicating strong internal reliability (Table 3).

\begin{tabular}{lcc}
\hline \multicolumn{1}{c}{ Scale } & Number of items & $\boldsymbol{\alpha}$ \\
\hline WLA: Workplace Learning Activity & 11 & .85 \\
SRL-F: forethought & 17 & .89 \\
SRL-P: performance & 19 & .88 \\
SRL-SR: self-reflection & 6 & .86 \\
WLC: Workplace Learning Context & 6 & .84 \\
\hline
\end{tabular}

Table 3. Cronbach Alpha for SRLWQ instrument scales.

\subsection{Exploratory factor analysis}

The underlying structure of each scale was investigated using principal component analysis. Analysis of the 11 item Workplace Learning Activity scale yielded a single factor (number of items: $11 ; \alpha=.85$; total explained variance: $45.58 \%$; Table 4 ) labelled workplace learning activity with highest loadings for intentional informal learning such as problem solving activities. The item which showed weakest loading was one representing the most 'formal' workplace learning activity: WLC7: 'Attending a training course or using self-study materials'.

\begin{tabular}{lc}
\hline \multicolumn{1}{c}{ Items } & Factor \\
\cline { 2 - 2 } & 1 \\
\hline [8] Observing or replicating colleagues' strategies to complete a task or solve a problem & .75 \\
[2] Working alone or with others to develop solutions to problems & .75 \\
[3] Working alone or with others to develop new ideas & .74 \\
[5] Performing new tasks & .74 \\
[11] Receiving feedback on tasks from work colleagues & .66 \\
[4] Following new developments in your field & .64 \\
[6] Asking colleagues for advice & .62 \\
[9] Finding better way to do a task by trial and error & .60 \\
[10] Reflecting on previous actions & .58 \\
[1] Acquiring new information (e.g. by searching the internet or company knowledge base) & .50 \\
[7] Attending a training course or using self-study materials & .45 \\
\hline
\end{tabular}

Table 4. Component Matrix (1 component extracted). Exploratory factor analysis for Workplace Learning Activity scale. Extraction Method: Principal Component Analysis. Total explained variance: $41.79 \%$.

The three SRL scales corresponding to the three phases of Zimmerman's model were analysed in turn. Each phase of the self-regulated learning process was measured by a separate scale in order to highlight the factor structure underlying the different phases. Analysis of the SRL-F (forethought phase) scale (number of items: $17 ; \alpha=.89$; total explained variance: $63.94 \%$; Table 5 ) yielded a four factor structure:

- F1: 'strategic planning' (number of items: $7 ; \alpha=.81$; total explained variance: $35.7 \%$; example item: 'I use specific strategies for different types of things I need to learn'). This factor is related to the actions undertaken to plan and organise learning in the workplace. 
This is a yellow-archive copy of the pre-print. Please find the final article at http://onlinelibrary.wiley.com/doi/10.1111/ijtd.12046/abstract and cite as: Fontana, R.P., Milligan, C., Littlejohn, A., and Margaryan, A. (2015) Measuring self-regulated learning in the workplace. International Journal of Training and Development. 19 (1) 32-52.

- F2: 'self-efficacy' (number of items: $4 ; \alpha=.81$; total explained variance: $12.88 \%$; example item: 'Whatever comes my way in my job, I can usually handle it') corresponds to the selfefficacy component of the SRL forethought phase, indicating the extent to which an individual feels confident to be able to accomplish all the tasks in his/her job.

- F3: 'goal setting' (number of items: $3 ; \alpha=.70$; total explained variance: 9.53\%; example item: 'I meet the goals that I set for myself in my job'). This factor relates to an individual's ability to set long or short term goals for their learning in the workplace.

- F4: 'task interest/value' (number of items: $3 ; \alpha=.80$; total explained variance: $5.83 \%$; example item: 'It is important for me to learn new things in this job'). This factor relates to the individual's personal interest in their task and the value they associate with its completion. Learners who are able to find personal interest or intrinsic value in a task are more likely to self-regulate their learning (Zimmerman, 2000).

\begin{tabular}{|c|c|c|c|c|}
\hline \multirow{3}{*}{ Items } & \multicolumn{4}{|c|}{ Factors } \\
\hline & 1 & 2 & 3 & 4 \\
\hline & $\begin{array}{l}\text { Strategic } \\
\text { planning }\end{array}$ & $\begin{array}{l}\text { Self- } \\
\text { efficacy }\end{array}$ & $\begin{array}{l}\text { Goal } \\
\text { setting }\end{array}$ & $\begin{array}{c}\text { Task } \\
\text { interest/ } \\
\text { value }\end{array}$ \\
\hline [19] I use specific strategies for different types of things I need to learn & .81 & & & \\
\hline [16] I ask myself questions about each learning task before I begin & .74 & & & \\
\hline [18] When planning my learning, I adapt strategies that have worked in the past & .69 & & & \\
\hline [14] I set goals to help me manage the time I spend learning & .65 & & & \\
\hline [15] I set realistic deadlines for learning when I have identified a learning need. & .62 & & & \\
\hline $\begin{array}{l}\text { [13] I set long-term goals (monthly or yearly) for myself in order to direct my } \\
\text { learning activities }\end{array}$ & .59 & & & \\
\hline [17] I think of several ways to solve a problem and choose the best one & .54 & & & \\
\hline $\begin{array}{l}\text { [48] I can remain calm when facing difficulties in my job because I can rely on } \\
\text { my abilities. }\end{array}$ & & .82 & & \\
\hline $\begin{array}{l}\text { [49] When I am confronted with a problem in my job, I can usually find several } \\
\text { solutions. }\end{array}$ & & .80 & & \\
\hline [50] Whatever comes my way in my job, I can usually handle it. & & .76 & & \\
\hline $\begin{array}{l}\text { [51] My past experiences in my job have prepared me well for my occupational } \\
\text { future. }\end{array}$ & & .54 & & \\
\hline [52] I meet the goals that I set for myself in my job. & & & .73 & \\
\hline [53] I feel prepared for most of the demands in my job. & & & .60 & \\
\hline [12] I set personal standards for performance in my job & & & .41 & \\
\hline [21] It is important for me to learn new things in this job & & & & .85 \\
\hline [22] Learning that I undertake in this job is important to me & & & & .84 \\
\hline [20] I think I will be able to use what I learn in this job in the future & & & & .77 \\
\hline
\end{tabular}

Table 5. Rotated Component Matrix. Exploratory factor analysis for SRL Forethought phase scale. Extraction Method: Principal Component Analysis for SRL Forethought phase scale. Rotation Method: Varimax with Kaiser Normalisation(rotation converged in 6 iterations). Total explained variance: $66.15 \%$.

All items in SRL-F load for a factor, however the factor structure that emerged is somewhat different to the original classification of the items. Three items that were classed originally as 'goal-setting' loaded instead for 'strategic planning'. Two factors from the 'self-efficacy' scale designed by Rigotti et al (2008) loaded with the 'goal-setting' factor.

For the performance phase scale, three factors were identified by this analysis (Table 6; total explained variance: $55.08 \%$ ).

- P1: 'elaboration strategies' (number of items: 6; $\alpha=.79$; total explained variance: $37.9 \%$; example item: 'During learning I treat the resources I find as a starting point and try to develop my own ideas from them'). This factor covers a number of sub-processes relating to help seeking and elaboration behaviour.

- P2: 'task strategies' (number of items: 6; $\alpha=.75$; total explained variance: 9.25\%; example item: 'I write down a plan to describe how I hope to achieve my learning goals'). This factor 
This is a yellow-archive copy of the pre-print. Please find the final article at http://onlinelibrary.wiley.com/doi/10.1111/ijtd.12046/abstract and cite as: Fontana, R.P., Milligan, C., Littlejohn, A., and Margaryan, A. (2015) Measuring self-regulated learning in the workplace. International Journal of Training and Development. 19 (1) 32-52.

represents a range of strategies and approaches an individual may employ to further their learning.

- P3: 'critical thinking' (number of items: 3; $\alpha=.80$; total explained variance: 7.9\%; example item: 'I try to play around with ideas of my own related to what I am learning'). This last factor describes an individual's ability to think critically about their learning.

As before the factor structure emerging from the principal component analysis differs slightly from the sub-process list used to select the original items. Four items $(35,36,40$ and 41$)$ did not load and no factors were identified corresponding to the 'sub-processes of 'help-seeking' and 'interest enhancement' identified by the Pintrich (2000) and Zimmerman (2000) models.

\begin{tabular}{|c|c|c|c|}
\hline \multirow[b]{2}{*}{ Items } & \multicolumn{3}{|c|}{ Factors } \\
\hline & $\begin{array}{c}1 \\
\text { elaboration } \\
\text { strategies }\end{array}$ & $\begin{array}{c}2 \\
\text { task } \\
\text { strategies }\end{array}$ & $\begin{array}{c}3 \\
\text { critical } \\
\text { thinking }\end{array}$ \\
\hline [37] When I am unsure about something I look it up & .77 & & \\
\hline [38] I fill in the gaps in my knowledge by getting hold of the appropriate material & .73 & & \\
\hline $\begin{array}{l}\text { [39] When faced with a challenge in my job I try to understand the problem as thoroughly as } \\
\text { possible }\end{array}$ & .58 & & \\
\hline $\begin{array}{l}\text { [30] When I'm learning, I bring together information from different sources (for example: } \\
\text { people and resources) }\end{array}$ & .54 & & \\
\hline [29] When I'm learning, I try to relate new knowledge I find to what I already know & .53 & & \\
\hline [31] I try to apply ideas from my previous experience to my job where appropriate & .52 & & \\
\hline [23] I write down a plan to describe how I hope to achieve my learning goals & & .66 & \\
\hline [28] I organize my time to best accomplish my goals & & 64 & \\
\hline [24] I ask myself how what I'm learning is related to what I already know. & & .64 & \\
\hline [25] I change strategies when I don't make progress while learning & & .62 & \\
\hline [26] When learning I make notes (including diagrams, etc.) to help organise my thoughts & & .60 & \\
\hline [27] I focus on the meaning and significance of new information & & .52 & \\
\hline [33] I try to play around with ideas of my own related to what I am learning & & & .80 \\
\hline $\begin{array}{l}\text { [32]During learning I treat the resources I find as a starting point and try to develop my own } \\
\text { ideas from them }\end{array}$ & & & .79 \\
\hline [34] In my job I think about possible alternative ways to do my tasks & & & .59 \\
\hline
\end{tabular}

Table 6. Rotated Component Matrix. Exploratory factor analysis for SRL Performance phase. Extraction Method: Principal Component Analysis for SRL Performance phase scale. Rotation Method: Varimax with Kaiser Normalisation (rotation converged in 3 iterations). Total explained variance: $\mathbf{5 5 . 0 8 \%}$.

Finally, for the self-reflection phase scale, two factors were identified (Table 7; total explained variance: $72.77 \%$ ). In this case, the factor structure emerging is consistent with the sub-process list used to select the original items.

- S1: 'self-satisfaction' (number of items: $3 ; \alpha=.85$; total explained variance: $59.35 \%$; example item: 'I consider how what I've learned relates to my team'; Table 7). Self-satisfaction refers to an individual's ability to recognise the intrinsic value of their recent learning beyond its immediate value (for example to longer term goals or to the organisation rather than just the individual).

- S2: 'self-evaluation' (number of items: 3; $\alpha=.82$; total explained variance: $16.24 \%$; example item: 'I ask myself if there were other ways to do things after I finish a task'; Table 7). This factor relates to an individual's ability to think about their recent learning experience and evaluate the actual learning that had occurred.

\begin{tabular}{lcc}
\hline \multicolumn{1}{c}{ Items } & \multicolumn{2}{c}{ Factors } \\
\cline { 2 - 3 } & $\begin{array}{c}\mathbf{1} \\
\text { Self-satisfaction }\end{array}$ & Self-evaluation \\
\hline [46-S-LS-7] I consider how what I've learned relates to my team & .88 \\
[47] I try to understand how new information I've learned impacts my work & .86 \\
[45] I think about how what I've learned fits in to the 'bigger picture' at my company & .77 & \\
[43] I ask myself if there were other ways to do things after I finish a task. & & .87 \\
\hline
\end{tabular}


This is a yellow-archive copy of the pre-print. Please find the final article at http://onlinelibrary.wiley.com/doi/10.1111/ijtd.12046/abstract and cite as: Fontana, R.P., Milligan, C., Littlejohn, A., and Margaryan, A. (2015) Measuring self-regulated learning in the workplace. International Journal of Training and Development. 19 (1) 32-52.

\begin{tabular}{lc}
\hline$[44]$ I think about what I've learned after I finish. & .82 \\
\hline [42] I know how well I have learned once I have finished a task & .75 \\
\hline Table 7. Rotated Component Matrix. Exploratory factor analysis for SRL Self-reflection phase \\
scale. Extraction Method: Principal Component Analysis for SRL Self-reflection phase scale. \\
Rotation Method: Varimax with Kaiser Normalisation (rotation converged in 3 iterations). Total \\
explained variance: $75.7 \%$.
\end{tabular}

Overall, the factor structure obtained for the three SRL scales is as shown in Table 8. Nine of the eleven sub-processes originally identified are represented. Two sub-processes (interest enhancement and help-seeking) are not represented by factors as the items loaded alongside items for elaboration, or did not load for any factor.

\begin{tabular}{l|lll}
\hline Scale & SRL-Forethought & SRL-Performance & SRL-Self-reflection \\
\hline Factor & Goal setting & Task strategies & Self-evaluation \\
& Strategic planning & Elaboration & Self-satisfaction/affect \\
& Self-efficacy & Critical Thinking & \\
& Task interest/value & & \\
\hline
\end{tabular}

Table 8 Phases and sub-processes emerging from principal component analysis of the 3 SRL scales

The Workplace Learning Context scale yielded a single factor structure encompassing all items (number of items: $6 ; \alpha=.84$; total explained variance: $55.11 \%$; example item: 'I can vary how I do my work'; Table 9) confirming the factor structure originally reported by Schalk and van Woerkom (2009). This factor relates to the perceived learning opportunities afforded by the role.

\begin{tabular}{lc}
\hline \multicolumn{1}{c}{ Items } & Factor \\
\cline { 2 - 2 } & $\mathbf{1}$ \\
\hline [56] I have opportunities to develop my own special abilities & .84 \\
[57] I can vary how I do my work & .81 \\
[54] My job requires me to be creative & .79 \\
[59] My job requires me to learn new things & .72 \\
[55] I can choose my job assignments & .70 \\
[58] My job requires a high level of skill & .61 \\
\hline
\end{tabular}

Table 9. Component Matrix. Exploratory factor analysis for the Workplace Learning Context scale (1 component extracted). Extraction Method: Principal Component Analysis. Total explained variance: $\mathbf{5 7 . 8 4 \%}$.

\subsection{Correlations}

The instrument was also tested for predictive validity. In their study of work-related learning among ICT workers, Gijbels et al. (2012), demonstrated a positive correlation between self-directed learning orientation and learning opportunities undertaken, arguing that self-directed learners are better able to identify learning opportunities, overcome barriers to learning and show learning initiative. Similarly, those who were not self-directed would fail to identify learning opportunities and fail to seize opportunities to learn. Although distinct concepts, self-regulated learning and self-directed learning are closely related (Pilling-Cormick \& Garrison, 2007) and in this study a similar hypothesis was formulated to test the predictive validity of the SRL scales (H1): High SRL score is positively correlated with Workplace Learning Activity. Learners who are better able to self-regulate their learning (including individual sub-processes) will be more aware of their learning needs, and more proactive about their learning, undertaking more workplace learning opportunities than their peers who are less able to self-regulate their learning. To test our hypothesis, correlation analysis between the factors identified by the principal component analysis of the SRL scales (F1, F2, F3, F4, P1, P2, S1, S2), as well as Total SRL score and Workplace Learning Activity was conducted (Table 9). Results indicate that Total SRL score is positively correlated with Workplace Learning Activity $(\mathrm{H} 1)$ and that each of the factors identified by the principal component analysis individually reflects this positive correlation (Table 10). 


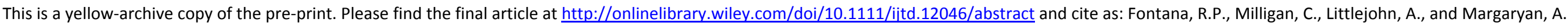
(2015) Measuring self-regulated learning in the workplace. International Journal of Training and Development. 19 (1) 32-52.

\begin{tabular}{|c|c|c|c|c|c|c|c|c|c|c|c|}
\hline & 1. & 2. & 3. & 4. & 5. & 6. & 7. & 8. & 9. & 10. & 11. \\
\hline 1. Workplace Learning Activity & 1 & $.61^{* *}$ & $.50^{* *}$ & $.20^{* *}$ & $.28^{* *}$ & $.46^{* *}$ & $.48^{* *}$ & $.52^{* *}$ & $.45^{* *}$ & $.42^{* *}$ & $.40^{* *}$ \\
\hline 2. Total SRL score & & 1 & $.84^{* *}$ & $.55^{* *}$ & $.67^{* *}$ & $.58^{* *}$ & $.79^{* *}$ & $.81^{* *}$ & $.70^{* *}$ & $.72^{* *}$ & $.61^{* *}$ \\
\hline 3. Forethought1: strategic planning & & & 1 & $.38^{* *}$ & $.53^{* *}$ & $.39^{* *}$ & $.57^{* *}$ & $.73^{* *}$ & $.51^{* *}$ & $.51^{* *}$ & $.43^{* *}$ \\
\hline 4. Forethought2: occupational self-efficacy & & & & 1 & $.61^{* *}$ & $.23^{* *}$ & $.37^{* *}$ & $.30^{* *}$ & $.29^{* *}$ & $.31^{* *}$ & $.24^{* *}$ \\
\hline 5. Forethought3: goal setting & & & & & 1 & $.30^{* *}$ & $.49^{* *}$ & $.45^{* *}$ & $.35^{* *}$ & $.39^{* *}$ & $.32^{* *}$ \\
\hline 6. Forethought4: task interest/value & & & & & & 1 & $.47^{* *}$ & $.40^{* *}$ & $.30^{* *}$ & $.42^{* *}$ & $.20^{* *}$ \\
\hline 7. Performance1: elaboration strategies & & & & & & & 1 & $.57^{* *}$ & $.62^{* *}$ & $.49^{* *}$ & $.40^{* *}$ \\
\hline 8. Performance 2: task strategies & & & & & & & & 1 & $.53^{* *}$ & $.51^{* *}$ & $.41^{* *}$ \\
\hline 10. Self-reflection1: self-satisfaction & & & & & & & & & & 1 & $.58^{* *}$ \\
\hline 11. Self-reflection2: self-evaluation & & & & & & & & & & & 1 \\
\hline
\end{tabular}

Table 10. Pearson correlations between workplace learning activity, workplace learning context and self-regulated learning dimensions. 
This is a yellow-archive copy of the pre-print. Please find the final article at http://onlinelibrary.wiley.com/doi/10.1111/ijtd.12046/abstract and cite as: Fontana, R.P., Milligan, C., Littlejohn, A., and Margaryan, A. (2015) Measuring self-regulated learning in the workplace. International Journal of Training and Development. 19 (1) 32-52.

\section{Conclusions}

This research aimed to develop and validate an instrument to measure self-regulated learning in the workplace. Starting from existing validated instruments developed in formal education settings, the instrument was adapted and designed to cover a broad range of sub-processes of SRL described by Pintrich (2000) and Zimmerman (2000). The instrument was then deployed as an online survey and completed by knowledge workers from the finance industry. Each of the five scales in the instrument show strong internal reliability. The factor structure emerging from the principal component analysis differs somewhat from the original design of the instrument where items were matched to specific sub-processes from the original Zimmerman and Pintrich models. Four items did not load for any factor and we eliminated these items from subsequent analysis. Other items loaded for a different factor than might have been anticipated. The factors are closely related and individual items may have been mis-categorised or their meaning changed when the wording was adapted to suit the workplace setting. Ultimately the strong internal reliability of the factors identified by the principal component analysis suggests that the factor structure indicated by the principal component analysis is robust. The factors identified by principal component analysis, as well as total SRL score and the workplace learning activity factor were used to perform a correlation analysis, confirming the hypotheses that SRL score would positively correlate with workplace learning activities undertaken and confirming the predictive validity of the instrument.

It is important to consider some of the limitations of the instrument, and of the current study. As highlighted in the introduction, the SRLWQ is a self-report measure and therefore may not provide a true measure of the extent to which an individual is capable of self-regulating their learning. Selfreport instruments are however widely used in the study of self-regulated learning and represent an appropriate mechanism for selecting learners who exhibit different behaviours as long as there is some recognition that the measures are relative, rather than absolute. This instrument is not intended to be used in isolation, but rather as one component of a wider study. Conducting research studies in any workplace can be a challenge as access to research subjects is restricted. We used a convenience sampling method to recruit participants for this study but nevertheless achieved a poor response rate. For the purposes of this study however, there is no reason to believe that the sample is unrepresentative. For future studies, alternative recruitment strategies which ensure a more coherent research cohort would be adopted. The data collected for this study was from workers in a single industry. Ideally, a similar study would be conducted with a different cohort to improve the generalizability of the findings and analyses.

The correlation analysis indicates that the SRLWQ instrument can be used to identify individuals who self-regulate their learning to different extents within their work-role and this can be valuable both for practice and research. Recognising those individuals who are more and less capable of selfregulation, and supporting them through the provision of support structures tailored to their specific needs becomes a means by which organisations can support their knowledge workers to become and remain effective employees. A modified version of this instrument could be deployed as a psychometric tool to allow organisations to match employees with specific profiles to different roles or provide tailored support. Similarly, by gaining a better understanding of their capacity to selfregulate their learning, knowledge workers can assume greater responsibility for their own learning and development. Employees could use a version of the instrument to assist them to reflect on their practice and identify areas for learning and development. For research, the availability of a tool that can differentiate between workers who self-regulate their learning to different degrees provides an opportunity for in depth analysis of the value of different SRL sub-processes in the workplace. The SRLWQ instrument is however only an initial step. To understand the nature of self-regulation of learning in the workplace more fully, the SRLWQ is intended to be used in conjunction with other methods. For example, in an extension of the present study, the SRLWQ will be used to identify knowledge workers with high and low SRL scores. These workers will then be interviewed to 
This is a yellow-archive copy of the pre-print. Please find the final article at http://onlinelibrary.wiley.com/doi/10.1111/ijtd.12046/abstract and cite as: Fontana, R.P., Milligan, C., Littlejohn, A., and Margaryan, A. (2015) Measuring self-regulated learning in the workplace. International Journal of Training and Development. 19 (1) 32-52.

determine the learning strategies they favour and learning strategies compared to determine the nature of any differences between the two groups. Further studies are also needed to develop our understanding of the precise nature of self-regulation of learning in the workplace.

\section{References}

Bandura, A. (1977). Self-efficacy: Toward a unifying theory of behavioral change. Psychological Review, 84, 191-215.

Bandura, A. (1986). Social foundations of thought and action: A social cognitive theory. Englewood Cliffs, NJ: Prentice Hall

Barnard-Brak, L., Lan, W. Y., \& Paton, V. O. (2010). Profiles in self-regulated learning in the online learning environment. International Review of Research in Open and Distance Learning, 11(1), 61-79.

Barnard-Brak, L., Lan, W. Y., \& Paton, V. O. (2011). Measuring and profiling self-regulated learning in the online learning environment. In G. Dettori \& D. Persico (Eds.), Fostering self-regulated learning through ICT (pp27-38), Hershey: Information Science Reference

Berings, M.G., M.C., Doornbos, A.J., and Simons, P. R.J. (2006). Methodological practices in on-thejob learning research. Human Resource Development International, 9(3), 333-363.

Van den Boom, G., Paas, F., van Merrienboer, J. \& van Gog, T. (2004) Reflection prompts and tutor feedback in a web based learning environment: effects on students self-regulated learning competence. Computers in Human Behavior, 20 (4) 551-567.

Chan, D. (2009). So why ask me? Are self-report data really that bad? In C. E. Lance and R.J. Vandenberg (Eds.), Statistical and methodological myths and urban legends: Doctrine, verity and fable in the organizational and social sciences (pp309-335). New York: Routledge

Crouse, P., Doyle, W., \& Young, J. D. (2011). Workplace learning strategies, barriers, facilitators and outcomes: a qualitative study among human resource management practitioners. Human Resource Development International, 14(1), 39-55.

Darlington, R. B., Weinberg, S., \& Walberg, H. (1973). Canonical variate analysis and related techniques. Review of Educational Research, 453-454.

Enos, M.D., Kehrhahn, M.T., \& Bell, A. (2003) Informal learning and the transfer of learning: how managers develop proficiency. Human Resource Development Quarterly, 14, 369-387.

Eraut M (2007) Learning from Other People in the Workplace. Oxford Review of Education, 33 (4), 403-422.

Ericsson, K. A., \& Simon, H. A. (1980). Verbal reports as data. Psychological Review, 87, 215-251.

Gijbels, D., Raemdonck, I., Vervecken, D., \& van Herck, J. (2012). Understanding work-related learning: the case of ICT workers. Journal of Workplace Learning, 24(6), 416-429.

Haeffel, G.J, Howard G.S. (2010) Self-Report: Psychology's Four-Letter Word. The American Journal of Psychology, 123(2), 181-188

Hager, P. (2004) The conceptualisation and measurement of learning at work. In H. Rainbird, A. Fuller, \& A. Munro (eds) Workplace Learning in Context. pp242-258. London: Routledge.

Hofer, B. Yu, S., \& Pintrich, P. R., (1998) Teaching college students to be self-regulated learners. In D.H. Schunk \& B. J. Zimmerman (Eds.). Self-regulated learning: from teaching to self-reflective practice (pp57-85). New York: Guidlford.

Littlejohn, A. \& Margaryan, A. (2013) Technology-enhanced professional learning: mapping out a new domain. in Littlejohn, A., \& Margaryan, A. (eds.). Technology-enhanced professional learning: Processes, practices and tools. pp1-13. London, Routledge.

Margaryan, A., Littlejohn, A., \& Milligan, C. (2013). Self-regulated learning in the workplace: Learning goal attainment strategies and factors. International Journal of Training and Development 17 (4).

Pilling-Cormick, J., \& Garrison, D.R. (2007) Self-directed learning and self-regulated learning: conceptual links. Canadian Journal of University Continuing Education 33 (2) 13-32. 
This is a yellow-archive copy of the pre-print. Please find the final article at http://onlinelibrary.wiley.com/doi/10.1111/ijtd.12046/abstract and cite as: Fontana, R.P., Milligan, C., Littlejohn, A., and Margaryan, A. (2015) Measuring self-regulated learning in the workplace. International Journal of Training and Development. 19 (1) 32-52.

Pintrich, P., Smith, D., Garcia, T., \& McKeachie, W. (1991). A manual for the use of the motivated strategies for learning questionnaire (MSLQ). Ann Arbor, MI: University of Michigan, National Center for Research to Improve Postsecondary Teaching and Learning

Pintrich, P. (2000) The role of goal orientation in self-regulated learning. In Boekaerts, M., Zeidner, M., and Pintrich, P.R (eds) Handbook of self-regulation, pp451-502. Academic Press: San Diego, CA.

Puustinen, M. \& Pulkkinen, L., (2001). Models of Self-regulated Learning: A review. Scandinavian Journal of Educational Research, 45:3, 269-286

Rigotti, T., Schyns, B., \& Mohr, G. (2008). A Short Version of the Occupational Self-Efficacy Scale: Structural and Construct Validity Across Five Countries. Journal of Career Assessment, 16(2), 238-255

Schalk, R., \& van Woerkom, M. (2009). Does age influence the relationship between learning opportunities at work and employee well-being and mobility? In L. Deitmer, L. Lassnigg, \& S. Manning (Eds.), Proceedings of the ECER VETNET Conference 2009: Papers presented for the VETNET programme of ECER 2009 'Theory and Evidence in European Educational Research' in Vienna (28 to 30 September 2009), Berlin: Wissenschaftsforum Bildung und Gesellschaft e.V.

Schraw, G. \& Dennison, R.S. (1994). Assessing metacognitive awareness. Contemporary Educational Psychology, 19, 460-475.

Schulz, M., \& Stamov Roßnagel, C. (2010). Informal workplace learning: An exploration of age differences in learning competence. Learning and Instruction, 20(5), 383-399.

Schunk, D.H. (2001). Social cognitive theory and self-regulated learning. In B.J. Zimmerman \& D.H. Schunk (Eds.), Self-regulated learning and academic achievement: Theoretical perspectives (2nd ed., pp. 125-152). Mahwah, NJ: Erlbaum

Sitzmann, T. \& Ely K. (2011). A meta-analysis of self-regulated learning in work-related training and educational attainment: what we know and where we need to go. Psychological Bulletin 137(3), 421-442.

Tynjälä, P. (2008). Perspectives into learning at the workplace. Educational Research Review, 3(2), 130-154.

van Eekelen, I. M., Boshuizen, H. P. A., \& Vermunt, J. D. (2005). Self-regulation in higher education teacher learning. Higher Education 50 () 447-471.

Warr, P., \& Downing, J. (2000). Learning strategies, learning anxiety and knowledge acquisition. British journal of psychology, 91, 311-333.

Winne, P. H., \& Jamieson-Noel, D. L. (2002). Exploring students' calibration of self-reports about study tactics and achievement. Contemporary Educational Psychology, 27, 551-572.

Zimmerman, B.J. (1989). A social cognitive view of self-regulated academic learning. Journal of Educational Psychology. 81:219-339.

Zimmerman, B. J. (2000). Attaining self-regulation: a social cognitive perspective. In Boekaerts, M., Zeidner, M., and Pintrich, P.R (Eds) Handbook of self-regulation, pp13-39. Academic Press, San Diego, CA.

Zimmerman, B. J. (2011). Motivational sources and outcomes of self-regulated learning and performance. in Zimmerman, B.J., and Schunk, D.H. (Eds) Handbook of self-regulation of learning and performance, 49-64. Routledge, London.

Zimmerman, B.J., \& Kitsantas, A. (1999). Acquiring writing revision skill: shifting from process to outcome self-regulatory goals. Journal of Educational Psychology, 91, 1-10 
This is a yellow-archive copy of the pre-print. Please find the final article at http://onlinelibrary.wiley.com/doi/10.1111/ijtd.12046/abstract and cite as: Fontana, R.P., Milligan, C., Littlejohn, A., and Margaryan, A. (2015) Measuring self-regulated learning in the workplace. International Journal of Training and Development. 19 (1) 32-52.

\section{Appendix.}

\section{Self-Regulated Learning at Work Questionnaire}

Items

The items used in the instrument are given below. The code to the left of each item (see key at end) indicates its origin.

\section{Personal details:}

[1- PD] Age

\section{[2- PD] Gender \\ Male \\ Female}

[3- PD] Your primary job role

Senior Manager

Supervisor

Frontline Staff

[4- PD] How many years have you worked for your current primary employer?

years.

\section{WORKPLACE LEARNING ACTIVITY Scale: WLA}

Question/Guidance:

Knowledge workers learn continually as they work, though they may not always be aware that they are learning. This section presents some possible learning activities you may have experienced during your work.

How frequently have you participated in the following learning activities in the last year?

1= never, $2=$ once or twice, $3=$ sometimes, $4=$ many times, $5=$ very often or always

Items

[1-LA-R-1] Acquiring new information (e.g. by searching the internet or company knowledge base)

[2-LA-R-2] Working alone or with others to develop solutions to problems

[3-LA-R-3] Working alone or with others to develop new ideas

[4-LA-R-4] Following new developments in your field

[5-LA-R-5] Performing new tasks

[6-LA-S-1] Asking colleagues for advice

[7-LA-C-1] Attending a training course or using self-study materials

[8-LA-C-5] Observing or replicating colleagues' strategies to complete a task or solve a problem

[9-LA-C-6] Finding better way to do a task by trial and error

[10-LA-C-8] Reflecting on previous actions

[11-LA-C-9] Receiving feedback on tasks from work colleagues

SELF-REGULATED LEARNING Scales: SRL-F, SRL-P and SRL-SR

Question/Guidance: Please indicate the extent to which the following statements describe your behaviour. There are no correct or incorrect responses to these questions: please indicate how you typically behave, rather than how you think you should behave.

Scale: 1 = not at all true for me, 2 =sometimes true for me, 3 = quite true for me, 4 = true for me,5 = very true for me

\begin{tabular}{|c|c|c|}
\hline SRL Phase & Sub-process & Items \\
\hline $\begin{array}{l}\text { SRL-F } \\
\text { FORETHOUGHT }\end{array}$ & Goal setting & $\begin{array}{l}\text { [12-F-OSLQ-1] I set personal standards for performance in my job } \\
\text { [13-F-OSLQ-2] I set long-term goals (monthly or yearly) for myself in } \\
\text { order to direct my learning activities } \\
\text { [14-F-OSLQ-4] I set goals to help me manage the time I spend learning } \\
\text { [15-F-OSLQ-4] I set realistic deadlines for learning when I have } \\
\text { identified a learning need. }\end{array}$ \\
\hline
\end{tabular}


This is a yellow-archive copy of the pre-print. Please find the final article at http://onlinelibrary.wiley.com/doi/10.1111/ijtd.12046/abstract and cite as: Fontana, R.P., Milligan, C., Littlejohn, A., and Margaryan, A. (2015) Measuring self-regulated learning in the workplace. International Journal of Training and Development. 19 (1) 32-52.

\begin{tabular}{|c|c|c|}
\hline & Strategic planning & $\begin{array}{l}\text { [16-F-MAI-22] I ask myself questions about each learning task before I } \\
\text { begin } \\
\text { [17-F-MAI-23] I think of several ways to solve a problem and choose } \\
\text { the best one } \\
\text { [18-F-MAI-3] When planning my learning, I adapt strategies that have } \\
\text { worked in the past } \\
\text { [19-F-MAl-18] I use specific strategies for different types of things I } \\
\text { need to learn }\end{array}$ \\
\hline & \begin{tabular}{|l|} 
Task \\
interest/value
\end{tabular} & $\begin{array}{l}\text { [20-F-MSLQ-4] I think I will be able to use what I learn in this job in the } \\
\text { future } \\
\text { [21-F-MSLQ-10] It is important for me to learn new things in this job } \\
\text { [22-F-MSLQ-27] Learning that I undertake in this job is important to me }\end{array}$ \\
\hline & $\begin{array}{l}\text { (Occupational) } \\
\text { self-efficacy }\end{array}$ & $\begin{array}{l}\text { [48-F-OS-1] I can remain calm when facing difficulties in my job } \\
\text { because I can rely on my abilities. } \\
\text { [49-F-OS-2] When I am confronted with a problem in my job, I can } \\
\text { usually find several solutions. } \\
\text { [50-F-OS-3] Whatever comes my way in my job, I can usually handle it. } \\
\text { [51-F-OS-4] My past experiences in my job have prepared me well for } \\
\text { my occupational future. } \\
\text { [52- F-OS-5] I meet the goals that I set for myself in my job. } \\
\text { [53-F-OS-6] I feel prepared for most of the demands in my job. }\end{array}$ \\
\hline \multirow[t]{5}{*}{$\begin{array}{l}\text { SRL-P } \\
\text { PERFORMANCE }\end{array}$} & Task strategies & $\begin{array}{l}\text { [23-P-MAI-37-39-41] I write down a plan to describe how I hope to } \\
\text { achieve my learning goals } \\
\text { [24-P-MAI-43] I ask myself how what I'm learning is related to what I } \\
\text { already know. } \\
\text { [25-P-MAI-40] I change strategies when I don't make progress while } \\
\text { learning } \\
\text { [26-P-MSLQ-32] When learning I make notes (including diagrams, etc.) } \\
\text { to help organise my thoughts } \\
\text { [27- P-MAI- 30] I focus on the meaning and significance of new } \\
\text { information } \\
\text { [28-P-MAl-45] I organize my time to best accomplish my goals }\end{array}$ \\
\hline & Elaboration & $\begin{array}{l}\text { [29-P-MSLQ-64] When I'm learning, I try to relate new knowledge I find } \\
\text { to what I already know } \\
\text { [30-P-MSLQ-53] When I'm learning, I bring together information from } \\
\text { different sources (for example: people and resources) } \\
\text { [31-P-MSLQ-81] I try to apply ideas from my previous experience to my } \\
\text { job where appropriate }\end{array}$ \\
\hline & Critical Thinking & $\begin{array}{l}\text { [32-P-MSLQ-51]During learning I treat the resources I find as a starting } \\
\text { point and try to develop my own ideas from them } \\
\text { [33-P-MSLQ-66] I try to play around with ideas of my own related to } \\
\text { what I am learning } \\
\text { [34-P-MSLQ-71] In my job I think about possible alternative ways to do } \\
\text { my tasks }\end{array}$ \\
\hline & Help seeking & $\begin{array}{l}\text { [35-P-MSLQ-68] When I can't understand a task, I ask my colleagues } \\
\text { for help. } \\
\text { [36-P-MSLQ-75] I try to identify colleagues in my workplace whom I } \\
\text { can ask for help if I need it } \\
\text { [37-P-LS -16] When I am unsure about something I look it up } \\
\text { [38-P-LS -18] I fill in the gaps in my knowledge by getting hold of the } \\
\text { appropriate material }\end{array}$ \\
\hline & \begin{tabular}{|l|} 
Interest \\
enhancement
\end{tabular} & $\begin{array}{l}\text { [39-P-MSLQ-22] When faced with a challenge in my job I try to } \\
\text { understand the problem as thoroughly as possible } \\
\text { [40-P-MSLQ-24] I like opportunities to engage in tasks that require me } \\
\text { to learn } \\
\text { [41-P-MSLQ-16] I prefer tasks that arouse my curiosity, even if I need }\end{array}$ \\
\hline
\end{tabular}


This is a yellow-archive copy of the pre-print. Please find the final article at http://onlinelibrary.wiley.com/doi/10.1111/ijtd.12046/abstract and cite as: Fontana, R.P., Milligan, C., Littlejohn, A., and Margaryan, A. (2015) Measuring self-regulated learning in the workplace. International Journal of Training and Development. 19 (1) 32-52.

\begin{tabular}{|c|c|c|}
\hline & & to learn to achieve them \\
\hline \multirow[t]{2}{*}{$\begin{array}{l}\text { SRL-SR } \\
\text { SELF- } \\
\text { REFLECTION }\end{array}$} & Self-evaluation & $\begin{array}{l}\text { [42-S-MAI-7] I know how well I have learned once I have finished a task } \\
\text { [43-S-MAI-18] I ask myself if there were other ways to do things after I } \\
\text { finish a task. } \\
\text { [44-S-MAI-24] I think about what I've learned after I finish. }\end{array}$ \\
\hline & $\begin{array}{l}\text { Self- } \\
\text { satisfaction/affect }\end{array}$ & $\begin{array}{l}\text { [45-S-LS-5] I think about how what I've learned fits in to the 'bigger } \\
\text { picture' at my company } \\
\text { [46-S-LS-7] I consider how what I've learned relates to my team } \\
\text { [47-S-LS-10] I try to understand how new information I've learned } \\
\text { impacts my work }\end{array}$ \\
\hline
\end{tabular}

WORKPLACE LEARNING CONTEXT SCale: WLC

Question/Guidance: Please indicate the extent to which your current role provides opportunities for learning and development. There are no correct or incorrect responses to these questions.

Scale: 1= never, 2= once or twice, 3= sometimes, $4=$ many times, 5= very often or always

Items

[54-WLC-1] My job requires me to be creative

[55-WLC-2] I can choose my job assignments

[56-WLC-3] I have opportunities to develop my own special abilities

[57-WLC-4] I can vary how I do my work

[58-WLC-5] My job requires a high level of skill

[59-WLC-6] My job requires me to learn new things

Key:

$\mathrm{F}=$ Forethought phase

$\mathrm{P}=$ Performance phase

$S=$ Self-reflection phase

Code for items: [no. in the current instrument - phase - origin - item no. in the original instrument] e.g. [1-F-

OSLQ-1] = [item no. 1 - forethought phase - OSLQ instrument - item no.1] 